\title{
ANALISIS RESIKO PRODUKSI DAN PENDAPATAN BUDIDAYA TAMBAK UDANG RAKYAT DI KELURAHAN LABUHAN DELI, KECAMATAN MEDAN MARELAN, KOTA MEDAN
}

\author{
Risk Analysis of Production and Income the Shrimp Cultivation of \\ the People in UrbanVillage Labuhan Deli, Sub District Medan \\ Marelan, Medan City \\ Nani Sura Saragih, Ketut Sukiyono, Indra Cahyadinata \\ Jurusan Sosial Ekonomi Pertanian Fakultas Pertanian Universitas Bengkulu \\ naniragih@gmail.com
}

\begin{abstract}
The aim of the research was (1) to analyze the risk of production (2) to analyze farmer's income, and (3) to analyze the risk of income. The research was conducted from June to July in 2014. Research area was chosen purposively in Urban Village Labuhan Deli, Sub District Medan Marelan, Medan City. The number of samples were 57 samples drawn by a simple random sampling. Data was analyzed using analisys of income and analisys of risk. The research result showed that shrimp cultivation earned $\mathrm{Rp}$ 19.571.547/Ha/Year. Meanwhile, based on the value of the coefficient variation's production that was 0.04 and the lower earnings was $142,60 \mathrm{Kg}$, it show that there was a little of risk faced by farmers. Then, based on the value of the coefficient variation's income that was 0.017, it showed that there was a little of risk faced by farmers and the lower earnings limit of shrimp cultuvation was $R p$ $6.304 .872,84 / \mathrm{Ha} /$ Year. This showed the lowest income that may be accepted by the farmers.
\end{abstract}

Keywords: shrimp farmer, risk, production, income

\section{PENDAHULUAN}

Salah satu komoditi yang potensial untuk diusahakan adalah Udang Windu, baik untuk pasar domestik maupun luar negeri. Udang Windu memiliki harga jual yang lebih tinggi dibanding dengan jenis komoditas budidaya yang lain. Amri (2003) mengatakan bahwa udang Windu merupakan komoditas ekspor andalan pemerintah untuk menggaet devisa negara. Selain itu, permintaan udang Windu cenderung meningkat baik dalam maupun luar negeri dengan tujuan utama ekspor ke Jepang, Eropa dan Amerik Serikat, bahkan di dalam negeri pedagang pengumpul besar dari kota-kota besar mencari langsung ke petani untuk membeli udang Windu. Namun demikian, usaha tambak udang Windu menghadapi banyak kendala. Misalnya penurunan 
jumlah produksi karena gagal panen yang disebabkan cuaca, iklim, banjir, atau faktor alam lainnya. Kualitas produk rendah mengakibatkan produk tersebut tidak dapat dijual atau harganya menjadi murah, sehingga berpengaruh kepada pendapatan petani tambak udang.

Setiap usaha bertujuan memperoleh keuntungan, begitu juga dengan para petani tambak udang rakyat di Medan Marelan. Namun, setiap usaha tidak akan terlepas dari kemungkinan resiko yang dapat menimbulkan kerugian besar bagi para pelaku usaha. Resiko yang paling mengancam dalam usaha tambak udang disebabkan oleh faktor alam, seperti iklim, cuaca, banjir dan serangan penyakit. Hal-hal seperti ini tentunya sulit untuk dikendalikan oleh manusia. Fluktuasi harga juga menjadi resiko dalam usaha tambak udang. Tingkat resiko yang dihadapi oleh usaha tambak udang ini dapat dianalisis dengan menggunakan analisis resiko, maka akan diketahui tingkat resiko yang dihadapi. Resiko yang diukur adalah resiko produksi, dan resiko pendapatan.

Kelurahan Labuhan Deli merupakan kelurahan yang berada di dalam kecamatan Medan Marelan, Kota Medan Provinsi Sumatera Utara memiliki luas area tambak udang sekitar 170 hektar dan potensi yang cukup besar terhadap komoditas udang, khususnya udang windu. Sebagian besar masyarakatnya membudidayakan udang windu secara tradisional dalam tambak.

Penelitian mengenai analisis resiko pada Petambak penting dilakukan karena untuk melihat kondisi nyata petambak udang windu di Kelurahan Labuhan Deli sehingga para petambak dapat mengambil keputusan yang tepat dalam menjalankan usaha dibidang budidaya udang windu sehingga dapat meminimalkan resiko yang akan terjadi. Selain itu, dapat memberikan masukan serta saran yang berguna ke depannya.

Berangkat dari penjelasan diatas, penelitian ini bertujuan untuk mengetahui tingkat produksi, dan pendapatan dari usaha budidaya tambak udang di Kelurahan Labuhan Deli, Kecamatan Medan Marelan, Kota Medan. Selain itu juga untuk menganalisis berapa besar tingkat resiko produksi dan resiko pendapatan petambak udang di Kelurahan Labuhan Deli, Kecamatan Medan Marelan, Kota Medan.

\section{METODE PENELITIAN}

Penelitian ini dilakukan di Kelurahan Labuhan Deli, Kecamatan Medan Marela, Kota Medan. Lokasi penelitian ditetapkan secara sengaja (purposive), dengan pertimbangan lokasi tersebut merupakan penghasil udang Windu dengan produktivitas terbesar di Kecamatan Medan Marelan.

Data yang akan diambil dalam penelitian ini yaitu bersumber dari data primer dan data sekunder. Data Primer, merupakan data yang diperoleh melalui wawancara langsung dengan petani tambak udang. Data Sekunder, 
yaitu data yang diperoleh dari literatur, baik dari buku, jurnal maupun dari hasil penelitian terdahulu yang digunakan sebagai data pelengkap atau penunjang dalam penelitian. Selain itu data sekunder juga dapat diperoleh dari berbagai instansi pemerintahan yang ada kaitannya dengan penelitian.

Metode pemilihan sampel dalam penelitian ini dilakukan dengan menggunakan metode sampling acak sederhana (Simple Random Sampling). Untuk mencari jumlah sampel, digunakan rumus menurut Sheaffer, Medenhall and Ott (1990). Dengan rumus ini, dapat dihitung jumlah sampel yang akan diambil dalam penelitian ini, yaitu 57 petani tambak udang.

\section{Metode Analisis Data}

Analisis data yang dilakukan pada penelitian ini terdiri dari analisis kualitatif dan analisis kuantitatif. Analisis kualitatif dilakukan melalui pendekatan deskriptif. Sedangkan analisis kuantitatif terdiri dari analisis resiko dengan menghitung expected value, ragam (variation), simpangan baku (standard deviation), koefisien variasi (standard variation), nilai batas bawah, produksi, harga dan pendapatan. Metode ini antara lain digunakan oleh Ihsanudin (2010) yaitu tentang resiko usahatani tembakau di Kabupaten Magelang, Lamusa (2010) menganalisis resiko usahatani padi sawah rumah tangga di daerah Impenso Provinsi Sulawesi Tengah, Arifin (2013) menganalisis resiko produksi dan pendapatan kepemilikan lahan daerah sentra produksi padi di Kabupaten Pinrang, Heriani dkk (2013) meneliti tentang analisis keuntungan dan resiko usahatanitomat di Kecamatan Sumberejo Kabupaten Tanggamus, dan Imelda (2012) meneliti tentang analisis resiko usaha pada penangkapan kepiting bakau di Kecamatan Sungai Kunyit Kabupaten Pontianak.

\section{Analisis Pendapatan dan Resiko pada Kegiatan Budidaya Tambak Udang}

Untuk mengetahui jumlah produksi dan harga jual dilakukan dengan wawancara langsung terhadap petani tambak. Untuk mengetahui pendapatan, dihitung dengan langkah-langkah perhitungan menurut Soekartawi (1995).

Penilaian resiko dapat dilakukan dengan mengukur nilai penyimpangan yang terjadi. Menurut Kadarsan (1995), untuk menganalisis resiko usaha dapat dilakukan dengan menggunakan langkah-langkah perhitungan hasil yang diharapkan (E). Dalam mengukur resiko secara sistematik, maka digunakan ukuran ragam (varian) dan simpangan baku (standar deviasi). Koefisien resiko merupakan perbandingan antara resiko yang harus ditanggung petambak dengan keuntungan yang akan diperoleh sebagai hasil dari sejumlah modal yang diinvestasikan dalam proses produksi. Hal ini menunjukkan semakin besar nilai koefisien resiko, maka semakin besar yang akan ditnggung petani tambak udang. 
Hubungan antara batas bawah hasil tertinggi (L) dengan koefisien variasi $(\mathrm{CV})$ yakni : Jika $\mathrm{CV}>0,5$ maka $\mathrm{L}<0$ artinya ada peluang kerugian yang akan diderita oleh perusahaan; Jika $\mathrm{CV}<0,5$ maka $\mathrm{L}>0$ artinya perusahaan akan selalu terhindar dari kerugian.

\section{HASIL DAN PEMBAHASAN}

\section{Karakteristik Petambak}

Berdasarkan hasil penelitian, umur petambak Udang Windu di lokasi penelitian bervariasi yaitu berkisar antara 28 tahun sampai 65 tahun, dengan rata-rata umur 45,81 tahun. Usia tersebut termasuk ke dalam usia produktif. Hal ini didukung dengan pendapat Mubyarto (1989), yang menyatakan bahwa usia produktif berkisar antara 15 - 64 tahun dan usia yang tidak produktif antara 0 - 14 tahun dan 65 tahun keatas. Petambak yang berada pada usia produktif akan memberikan hasil kerja yang maksimal jika dibandingkan dengan usia yang tidak produktif. Karena pada usia produktif umumnya seseorang memiliki kemampuan yang lebih baik dalam berfikir dan bertindak untuk melakukan kegiatan. Persentase umur terbesar dari petambak Udang Windu di daerah penelitian berada pada kategori kelompok umur (41 tahun-53 tahun) yaitu sebesar $56,14 \%$ atau 32 orang. Selanjutnya diikuti kategori kelompok umur (28 tahun- 40 tahun ) sebesar 28,07 \%, dan kelompok umur yang terkecil adalah kategori kelompok umur (54 tahun- 65 tahun) sebesar 15,79\% atau 9 orang. Umur akan mempengaruhi banyak atau sedikitnya pengalaman petani tambak udang dalam usaha bididaya tambak udang. Lamanya pengalaman pengelolaan akan dapat meningkatkan produksi.

Tingkat pendidikan seseorang pada umumnya dapat mempengaruhi pola berpikir dalam mengelola usahanya. Semakin tinggi pendidikan seseorang, maka akan semakin luas wawasannya dan semakin membuka diri terhadap kemajuan teknologi. Data penelitian menunjukkan bahwa tingkat pendidikan formal Petambak Udang yang terbesar adalah berada di kategori kelompok (9 tahun-13 tahun) yaitu sebesar $70,18 \%$ atau 40 orang. Melihat kondisi ini, dapat dilihat bahwa tingkat pendidikan Petambak Udang Windu di daerah penelitian cukup baik. Tingginya tingkat pendidikan ini akan mempengaruhi pola pikir petani tambak dalam mengadopsi informasiinformasi. Petani tambak udang diharapkan dapat dengan mudah menyerap informasi tentang usaha budidaya tambak udang baik lewat radio, televisi, surat kabar ataupun sumber informasi lainnya.

Tanggungan keluarga yang dimaksud adalah semua orang yang tinggal bersama kepala keluarga dan tidak tinggal bersama keluarga tetapi hidupnya masih dibiayai oleh kepala keluarga. Data penelitian menunjukkan rata-rata jumlah tanggungan keluarga petambak udang 
adalah 2 orang sampai 3 orang dengan presentase sebesar 71,93\%. Jumlah anggota keluarga ini mempengaruhi pengeluaran atau konsumsi keluarga petambak. Sehingga hal ini akan mendorong pengelola untuk tidak menggunakan tenaga kerja luar dalam setiap proses pekerjaan dalam usaha budidaya tambak udang. Dengan tidak terlalu banyak menggunakan tenaga kerja luar, maka biaya yang dikeluarkan juga tidak terlalu banyak, sehingga keuntungan yang diperoleh petambak semakin besar.

Data penelitian menunjukkan, lama pengalaman usaha tambak yang paling banyak berada pada kategori 1,5 tahun sampai 10 tahun dengan persentase sebesar $75,44 \%$. Pengalaman bertambak ini akan membantu petambak dalam mengolah tambak udangnya, karena pengalaman dalam berusaha budidaya tambak udang merupakan salah satu faktor yang mendukung petambak dalam menjalankan usahanya dengan lebih baik, serta lebih bijak dalam menyikapi setiap perubahan yang terjadi, baik yang mendatangkan kerugian maupun keuntungan dari hasil kegiatan tersebut. Sehingga hal ini dapat membantu petambak dalam mengambil keputusan untuk usaha periode musim tebar berikutnya.

Rata- rata luas lahan yang digarap oleh petambak berada pada kategori 0,5 Ha samapi 1,66 Ha yairu sebanyak 52 orang dengan persentase 91,23\%. Perbedaan luas lahan ini disebabkan oleh kemampuan modal untuk membeli atau menyewa lahan budidaya tambak udang. Pada umumnya, di daerah penelitian ini semakin luas lahan yang dimiliki maka petani tambak akan menggunakan banyak tenaga kerja luar keluarga. Semakin banyak menggunakan tenaga kerja luar keluarga, maka semakin besar pula biaya yang harus dikeluarkan oleh petani tambak udang. Jadi, luas lahan ini akan mempengaruhi besar atau kecilnya biaya produksi yang dikeluarkan oleh petani tambak udang.

Status kepemilikan lahan petambak udang di daerah penelitian yang lebih banyak adalah lahan milik sendiri. Persentase status lahan milik sendiri adalah $66,67 \%$ atau sebanyak 38 orang. Ada juga petambak yang menyewa lahan yaitu sebanyak 19 orang dengan persentasi 33,33\%.

\section{Biaya Usaha Budidaya Tambak Udang}

Biaya yang dikeluarkan dalam usaha budidaya tambak Udang ini ada dua jenis yaitu biaya tetap dan biaya variabel. Menurut Mulyadi (2007) biaya tetap adalah biaya yang jumlah totalnya tetap dalam volume kegiatan tertentu dan waktu tertentu, sedangkan biaya variabel adalah biaya yang dalam jumlah totalnya akan berubah sebanding/proporsional dengan perubahan volume kegiatan produksi. 


\section{Biaya Tetap}

Biaya yang menjadi biaya tetap pada usaha budidaya tambak Udang di daerah penelitian adalah biaya penyusutan alat, dan biaya pajak lahan. Gambaran rata-rata penggunaan biaya tetap pada usaha budidaya tambak Udang dapat dilihat pada Tabel 1 berikut:

Tabel 1. Rata-rata Total Biaya tetap pada Usaha Tambak Udang Windu

\begin{tabular}{|c|c|c|c|c|c|c|c|c|}
\hline \multirow{2}{*}{ Uraixn } & \multicolumn{2}{|c|}{ MT I } & \multicolumn{2}{|c|}{ MT II } & \multicolumn{2}{|c|}{ MT III } & \multicolumn{2}{|c|}{ Rata-rata Tntal } \\
\hline & $(\mathrm{Kp} / \mathrm{MT})$ & $(\mathrm{Kp} / \mathrm{H} a)$ & (Kр/MI) & $\left(\mathrm{R}_{\mathrm{p}} / \mathrm{H} \mathrm{a}\right)$ & (Kp/MT) & $(\mathrm{Kp} / \mathrm{H} a)$ & $(\mathrm{Kp} / \mathrm{MT})$ & $(\mathrm{Kp} / \mathrm{H} \mathrm{a})$ \\
\hline $\begin{array}{l}\text { a. Penfusulan } \\
\text { alat }\end{array}$ & 213466,37 & 305732,30 & 213466,37 & 305732,30 & 213466,37 & 305732,30 & 640399,12 & 917196,91 \\
\hline $\begin{array}{l}\text { b. Pajak } \\
\text { lahan }\end{array}$ & 2824,56 & 89473,68 & 29824,56 & 89473,18 & 29824,56 & 89473,68 & 89473,68 & 268421,05 \\
\hline $\begin{array}{l}\text { c. SEwy } \\
\text { lahan }\end{array}$ & 194736,84 & 584210,53 & 194736,84 & 584210,53 & 194736,84 & 584210,53 & 584210,53 & 1752631,58 \\
\hline $\begin{array}{r}\text { Junlal } \\
\text { Sumber : }\end{array}$ & $\begin{array}{l}438 M 7,78 \\
\text { ata }\end{array}$ & $\begin{array}{l}\text { 979416,51 } \\
\text { er Dioll }\end{array}$ & $\begin{array}{l}\mathbf{4 3 8 0 1 2 7 , 7 8} \\
2015\end{array}$ & 979416,51 & $488,07,78$ & 979416,51 & 1314083,33 & 2338246,54 \\
\hline
\end{tabular}

Biaya penyusutan ini dihitung dalam biaya penyusutan per bulan dengan dasar perhitungan harga awal dikurangi harga akhir dan dibagi umur ekonomis, sehingga besar kecilnya rata-rata biaya penyusutan yang harus dikeluarkan oleh petani sangat tergantung oleh besar kecilnya rata- rata nilai ketiga komponen tersebut. Dari hasil perhitungan, didapat rata-rata biaya total penyusutan alatnya adalah sebesar Rp 213.466,37/MT. Hal ini disebabkan oleh waktu produksi yang digunakan pada masing-masing musim adalah sama, dimana perhitungan biaya penyusutan dihitung tiap bulannya dan untuk kegiatan budidaya hingga panen berlangsung selama 3 bulan.

Petambak Udang wajib mengeluarkan biaya pajak untuk lahan yang digunakan sebagai tempat budidaya tambak Udang tersebut. Dasar perhitungan pajak untuk setiap tahun per hektar adalah perbandingan luas lahan dikalikan dengan besarnya pajak per tahun per hektarnya dibagi dengan periode musim tebar. Di daerah penelitian, biaya pajak per hektar per tahun adalah Rp 75.000. Dari data Tabel 1 menunjukkan bahwa ratarata biaya pajak yang dikeluarkan setiap musimnya adalah sama, yaitu sebesar Rp 43.421,05/MT. Hal ini dikarenakan tidak ada peningkatan luas lahan tambak yang digunakan oleh petani tambak.

Sebagian kecil responden yang status lahannya adalah sewa, sehingga ini dikenakan biaya tambahan yaitu biaya sewa lahan yang dihitung pertahun dan berdasarkan luas lahan yang di sewa. Total rata-rata biaya sewa lahan yang harus dikeluarkan petambak udang penyewa adalah sebesar Rp 194.736,84/MT setiap musimnya. Hal ini dikarenakan biaya sewa sudah dibayar selama satu tahun, sehingga biaya permusim diperoleh dari biaya pertahun 
dibagi dengan banyak jumlah lahan itu digunakan dalam satu tahun, yaitu sebanyak 3 kali musim tebar.

\section{Biaya Variabel}

Biaya variabel pada usaha budidaya tambak Udang di daerah penelitian adalah biaya input produksi dan biaya tenaga kerja harian. Rata-rata biaya variabel tersebut dapat dilihat pada Tabel 2 berikut:

Tabel 2. Rata-rata Biaya Variabel Usaha Budidaya Tambak Udang Windu

\begin{tabular}{|c|c|c|c|c|c|c|c|c|}
\hline \multirow{2}{*}{ Uraian } & \multicolumn{2}{|c|}{ MT I } & \multicolumn{2}{|c|}{ MT II } & \multicolumn{2}{|c|}{ MT III } & \multicolumn{2}{|c|}{ Rata-rata Total } \\
\hline & (Rp/MT) & (Rp/Ha) & $\left(\mathrm{R}_{\mathrm{p}} / \mathrm{MT}\right)$ & (Rp/Ha) & (Rp/MT) & (Rp/Ha) & (Rp/MT) & (Rp/Ia) \\
\hline a. Benur & 521.053 & 600.000 & 521.053 & 600.000 & 521.053 & 600.000 & 1.563 .158 & 1.800 .000 \\
\hline \multicolumn{9}{|l|}{ b. Pupuk } \\
\hline Urea & 132.895 & 155.263 & 132.895 & 155.263 & 132.895 & 155.263 & 398.684 & 465.789 \\
\hline SP36 & 91.184 & 105.000 & 91.184 & 105.000 & 91.184 & 105.000 & 273.553 & 315.000 \\
\hline c. Pakan & 2.605 .263 & 3.000 .000 & 2.605 .263 & 3.000 .000 & 2.605 .263 & 3.000 .000 & 7.815 .789 & 9.000 .000 \\
\hline d. Obat-obatan & 62.526 & 72.000 & 62.526 & 72.000 & 62526 & 72.000 & 187.579 & 216.000 \\
\hline d. Kaарur & 130.263 & 150.000 & 130.263 & 150.000 & 130.263 & 150.000 & 390.789 & 450.000 \\
\hline \multicolumn{9}{|l|}{ e. Bahan Bakar } \\
\hline Solar & 125.439 & 138.268 & 125.439 & 138.268 & 125.439 & 138.268 & 376.316 & 414.803 \\
\hline Minyak Tanah & 87.719 & 134.503 & 87.719 & 134.503 & 87.719 & 134503 & 263.158 & 403.509 \\
\hline f. Tenaqa Kerja & 3.187 .953 & 4.286345 & 3.187953 & 4.286 .345 & 3.187953 & 4.286345 & 9.563 .860 & 12.859 .035 \\
\hline Total & 6.944 .295 & 8.641379 & 6.944 .295 & 8.641379 & 6.941 .295 & 8.641379 & 20.832 .886 & 25.924 .136 \\
\hline
\end{tabular}

Sumber : Data Primer Diolah, 2015

Biaya variabel ini adalah biaya yang dikeluarkan setiap periode 3 bulan dan selama kegiatan usaha budidaya berlangsung. Biaya variabel yang dikeluarkan setiap periode musim tebar adalah sama, dimana satu tahun ada 3 kali periode musim tebar dan rata-rata total biaya per periode musim tebar adalah sebesar Rp 6.944.295/MT atau sebesar Rp 8.641.379/Ha. Pada biaya Variabel ini, biaya yang paling besar digunakan adlah pada biaya tenaga kerja, dimana rata-rata total biaya tenaga kerja yang harus dikeluarkan setiap periode musim tebar adalah sebesar Rp 3.187.953,22/MT atau sebesar Rp 8.641.378,65/Ha. Tingginya biaya tenaga kerja ini dikarenakan upah tenaga kerjanya yang cukup tinggi yaitu Rp 50.000 / hari kerja.

\section{Total Biaya}

Total biaya merupakan seluruh biaya yang dikeluarkan dalam usaha budidaya tambak Udang, yaitu penjumlahan dari total biaya tetap dan total biaya variabel. Rincian tentang rata-rata total biaya tersebut ditampilkan pada Tabel 3. 
Tabel 3. Rata-rata Total Biaya pada usaha budidaya Tambak Windu

\begin{tabular}{|c|c|c|c|c|c|c|c|c|}
\hline \multirow[t]{2}{*}{ Draina } & \multicolumn{2}{|l|}{ MTI } & \multicolumn{2}{|c|}{ MT II } & \multicolumn{2}{|l|}{ MTIII } & \multicolumn{2}{|c|}{ Rata-rata Total } \\
\hline & (Rp/MI) & $(\mathbf{R p} / \mathrm{Ha})$ & (Kp/MI) & $\left(\mathbf{R p}_{\mathrm{p}} / \mathrm{Ha}\right)$ & (Rp/MI) & (Rp/Ha) & (Rp/MI) & $(\mathrm{Kp} / \mathrm{H} / \mathrm{a})$ \\
\hline $\begin{array}{l}\text { Biaya } \\
\text { Tetap }\end{array}$ & 438.028 & 979.417 & 438.028 & 979.417 & 438.028 & 979.417 & 1314.083 & 2938.250 \\
\hline $\begin{array}{l}\text { Diaya } \\
\text { Variabel }\end{array}$ & 6944295 & 8.641 .379 & 6.944295 & 8.641 .379 & 6944295 & 8.641379 & 20.832 .886 & 25.924 .136 \\
\hline Total & 7382323 & 9.624 .75 & 7.382 .323 & $9.620 .7 \%$ & 7.382323 & 9.620 .795 & 22.146 .969 & 28.862 .386 \\
\hline
\end{tabular}

Sumber : Data Primer Diolah , 2015

Dari penjumlahan biaya tetap dan biaya variabel diperoleh rata-rata total biaya yang dikeluarkan setiap periode musim tebar sebesar Rp 7.382.323/MT atau Rp 9.620.795/Ha. Total biaya yang dikeluarkan setiap musim tebar adalah sama, hal ini dikarenakan tidak adanya kenaikan harga bahan input produksi selama satu tahun periode musim tersebut. Selain tidak ada kenaikan harga bahan input produksi, hal ini juga dikarenakan tidak adanya penambahan kapasitas input produksi pada setiap periode musim tebarnya dan penggunaan jumlah tenaga kerja juga tetap setiap periode musim tebarnya. Alasan kenapa petambak menggunakan jumlah yang tetap dalam penggunaan tenaga kerja setiap musimnya adalah, karena mereka sudah memperkirakan berapa orang yang dibutuhkan untuk bekerja di luas lahan yang mereka miliki. Apabila penggunaan tenaga kerja ditambah, maka akan mengurangi pendapatan petambak, namun apabila tenaga kerja dikurangi, maka petambak mengkhawatirkan hasil pekerjaannya tidak optimal.

\section{Produksi dan Penerimaan Usaha Budidaya Tambak Udang Windu}

Rincian tentang rata-rata jumlah produksi dan penerimaan usaha budidaya tambak Udang Windu di daerah penelitian disajikan dalam Tabel 4 di bawah ini.

Tabel 4. Total Produksi dan Penerimaan Usaha Tambak Udang Windu

\begin{tabular}{|c|c|c|c|c|c|c|c|c|}
\hline \multirow[t]{2}{*}{ No } & \multirow[t]{2}{*}{ Uraían } & \multicolumn{2}{|c|}{ Ukuran (Kg) } & \multicolumn{4}{|c|}{ Rula-rataPuntrimann (Rp) } & \multirow{2}{*}{$\begin{array}{c}\text { Total } \\
\text { Penerimaan }\end{array}$} \\
\hline & & 30 & 35 & 40 & 30 & 35 & 40 & \\
\hline \multirow{9}{*}{$\frac{1}{2}$} & Mr/ur & & & & & & & \\
\hline & T I & 74 & 46 & 10 & 7.762 .632 & 4.570 .175 & 846.842 & 13.179 .649 \\
\hline & $\mathbf{T} \mathbf{\Pi}$ & 71 & 12 & 9 & 8.172 .807 & 1.212 .105 & 785.088 & 1.3200 .000 \\
\hline & III & 64 & 50 & 5 & 7.6200 .351 & 4.973 .684 & 454.386 & 13.118 .421 \\
\hline & MT/HA & & & & & & & \\
\hline & MT I & 81 & 66 & 9 & 8.769 .619 & 6.592 .105 & 785.109 & 16.117.1G1 \\
\hline & MT II & 83 & 64 & 9 & 9.083 .845 & 6.437 .427 & 731579 & 16252.851 \\
\hline & MT II & 69 & 73 & 5 & 8.271 .930 & 7.324561 & 437.427 & 16.033918 \\
\hline & Jumlah & 235 & 204 & 24 & 26.125 .424 & 20.354_(694 & 1.954 .415 & 48.433 .533 \\
\hline
\end{tabular}

Sumber : Data Primer Diolah, 2015 
Pada usaha budidaya tambak udang di Kelurahan Labuhan Deli, petani tambak udang melakukan pemanenan dalam waktu 3 bulan sekali. Hasil panen di jual ke agen yang langsung datang ke lokasi pemanenan udang. Jadi, hal ini sangat menguntungkan para petani tambak, karena mereka tidak perlu lagi mengeluarkan biaya transportasi atau biaya upah tenaga kerja untuk menjual hasil panen langsung ke pabrik.

Ada 3 ukuran dalam penjualan Udang Windu tersebut, yaitu ukuran 30, ukuran 35 dan ukuran 40. Maksud dari ukuran tersebut adalah, berat udang per kilogram itu adalah 30, 35 atau 40 ekor udang. Harga dari setiap ukuran juga berbeda-beda. Harga dari ukuran 30 adalah Rp 105.000/Kg, sedangkan untuk ukuran 35 adalah $100.000 / \mathrm{Kg}$ dan yang terakhir adalah ukuran 40 dengan harga Rp80.000/Kg. Tetapi pada saat periode panen musim tebar II dan musim tebar III, harga udang ukuran 30 naik sebesar Rp 5000/Kg, dari harga sebelumnya yaitu Rp 105.000/Kg menjadi Rp 110.000/Kg, sedangkan harga untuk ukuran 40 juga mengalami kenaikan pada saat panen di musim tebar III sebesar Rp 10.000/Kg, dari harga sebelumnya yaitu $\mathrm{Rp} 80.000 / \mathrm{Kg}$ menjadi Rp,90.000/Kg. Dilihat dari ketiga musim tebar tersebut, peningkatan harga terjadi pada musim tebar III, namun jumlah produksi yang paling sedikit juga terjadi pada musim tebar III tersebut.

Adanya perbedaan harga dan perbedaan jumlah produksi mempengaruhi penerimaan masing-masing petani tambak udang. Semakin tinggi harga dan jumlah produksi, maka semakin besar pula penerimaan petambak udang.

\section{Pendapatan}

Pendapatan merupakan hasil pengurangan dari total penerimaan dengan total biaya.

Tabel 5. Pendapatan Usaha Tambak Udang Windu

\begin{tabular}{|c|c|c|c|c|c|c|c|c|}
\hline \multirow{2}{*}{ Unial } & \multicolumn{2}{|c|}{ MTI } & \multicolumn{2}{|c|}{ MTII } & \multicolumn{2}{|c|}{ प्रTIII } & \multicolumn{2}{|c|}{ Rata-rata Total } \\
\hline & (Rp/MT) & $\left(R_{p} / H a\right)$ & RPMT) & (Rp/Ha) & pMT) & $\left(\mathbf{R}_{\mathrm{p}} / \mathrm{Ha}\right)$ & (RpMT) & (Rp/Ha) \\
\hline & 13.179 .649 & 16.147 .164 & 13200.000 & 16252.851 & 13.118.421 & 16.033 & 39.498 .070 & 48.433 .933 \\
\hline Biaya & 7.382323 & 9.620 .795 & 7382323 & 9.620 .795 & 7.382323 & 9.620 .795 & 22.146 .969 & 28.862 .386 \\
\hline Peadapatan & 5.797326 & 6.526 .369 & 5817.677 & 6.632 .156 & 5.736 .098 & 6.413.123 & 17351.101 & 19571.547 \\
\hline
\end{tabular}

Sumber : Data Primer Diolah, 2015

Berdasarkan Tabel 5 diketahui rata-rata pendapatan petambak udang terbesar yaitu pada periode MT II yaitu sebesar Rp 5.817.677/MT atau Rp 6.632.056/Ha. Hal ini dikarenakan pada MT II jumlah produksi nya lebih banyak dibanding dengan jumlah produksi di dua musim tebar lainnya. Menurut petambak, cuaca dan iklim pada saat periode musim tebar II baik, 
jarang turun hujan yang menyebabkan tambak banjir. Faktor alam yang bersahabat ini membantu kelancaran proses budiddaya. Selain itu, pada musim tebar II juga mengalami kenaikan harga yaitu pada ukuran 35. Hal ini juga mempengaruhi besarnya pendapatan yang akan diterima oleh petani tambak. Peningkatan jumlah produksi dan peningkatan harga tersebut menyebabkan pendapatan pada musim tebar II lebih besar dibanding dengan pendapatan pada dua musim tebar lainnya.

\section{Analisis Resiko Produksi dan Pendapatan}

Analisis resiko sangat penting bagi petani tambak dalam pengambilan keputusan sebelum mereka memulai usaha nya. Pendekatan analisa resiko didasarkan kepada hasil yang diperoleh oleh petani tambak Udang selama periode tertentu. Data yang digunakan untuk menganalisis resiko petani tambak Udang adalah data Produksi dan pendapatan dari hasil penerimaan budidaya tambak Udang selama 3 musim tebar atau musim panen.

\section{Analisis Resiko Produksi}

Resiko produksi yang terjadi dapat diakibatkan karena serangan hama dan penyakit baik secara mendadak dan bersifat meluas. Sehingga dapat mengakibatkan penurunan hasil hingga 65\% bahkan dapat menyebabkan gagal panen (Cahyono, 2008).

Rincian analisis resiko produksi pada usaha budidaya tambak udang dapat dilihat pada Tabel 6 berikut:

Tabel 6. Analisis Resiko Produksi Usaha Budidaya Tambak Udang Windu

\begin{tabular}{llc}
\hline No & Periode & Produksi $\mathbf{( K g} / \mathbf{H a})$ \\
\hline 1 & Musim Tebar I & 158,88 \\
2 & Musim Tebar II & 155,81 \\
3 & Musim Tebar III & 147,72 \\
\hline
\end{tabular}
a. Rata-rata (E)
154,14
b. Varian ( $\left.\mathrm{V}^{2}\right)$
33,26
c. Simpangan Baku (V)
5,77
d. Koefisien Variasi (CV)
0,04
e. Batas Bawah (L)
142,60

Sumber : Data Primer Diolah, 2015 


\section{Hasil yang Diharapkan (E)}

Hasil yang diharapkan dihitung dari jumlah produksi yang diperoleh petambak pada tiga periode musim tebar dan dibagi dengan banyaknya periode. Nilai tersebut menggambarkan jumlah produksi bersih yang diharapkan petambak setiap proses produksi dimasa yang akan datang. Nilai rata-rata jumlah produksi pengamatan yaitu $154,14 \mathrm{Kg}$. Angka tersebut merupakan nilai hasil yang diharapkan oleh petambak pada periode masa datang.

\section{Ragam atau Varian $\left(V^{2}\right)$}

Semakin besar nilai varian yang dihasilkan, maka akan semakin besar penyimpangan yang terjadi sehingga resiko yang dihadapi petambak pun semakin besar. Begitu pula sebaliknya, semakin kecil nilai varian yang dihasilkan, maka semakin kecil pula resiko yang akan dihadapi oleh para petambak udang. Beradasarkan tabel diatas, nilai varian yang diperoleh yaitu 33,26. Nilai varian yang diperoleh kecil, sehingga penyimpangan yang terjadi juga kecil. Artinya, penyimpangan tersebut menunjukkan bahwa tingkat resiko produksi petambak udang kecil.

\section{Simpangan Baku (V)}

Simpangan baku merupakan akar kuadrat dari nilai varian. Nilai varian yang dihasilkan akan berbanding lurus dengan simpangan baku. Semakin besar simpangan baku, maka akan semakin besar resiko yang dihadapi. Semakin kecil simpangan baku maka semakin kecil resiko yang dihadapi. Dari hasil perhitungan, simpangan yang diperoleh adalah 5,77. Nilai tersebut menunjukkan bahwa tingkat resiko produksi yang dihadapi oleh petambak udang pada setiap periode dimasa yang akan datang. Nilai simpangan baku tersebut mengindikasikan bahwa tingkat resiko produksi yang dihadapi oleh petambak udang kecil.

\section{Koefisien Variasi (CV) dan Nilai Batas Bawah (L)}

Koefisien variasi merupakan perbandingan antara nilai simpangan baku dengan nilai hasil yang diharapkan. Semakin besar nilai koefisien variasi yang didapatkan, maka semakin besar pula resiko yang dihadapi. Semakin kecil nilai keofisien variasi yang didapatkan, maka semakin kecil pula resiko yang dihadapi. Berdasarkan hasil perhitungan, nilai koefisien 
variasi yang diperoleh adalah sebesar 0,04. Artinya, untuk setiap $1 \mathrm{Kg}$ yang diperoleh petani, akan menghasilkan resiko sebesar 0,04 Kg.

Nilai batas bawah diperoleh dari selisih antara hasil yang diharapkan dengan dua kali simpangan baku. Dari hasil perhitungan, nilai L yang diperoleh yaitu sebesar 142,60 Kg/Ha. Angka-angka tersebut menunjukkan batas minimal produksi yang harus dihasilkan petambak dimasa mendatang. Apabila dilihat dari kriteria hubungan antara nilai $\mathrm{CV}$ dan $\mathrm{L}$ yaitu apabila $\mathrm{CV}$ $>0,5$ maka $\mathrm{L}<0$, maka usaha tersebut akan berpeluang mengalami kerugian, apabila $\mathrm{CV}<0,5$ maka $\mathrm{L}>0$ maka usaha tersebut akan terhindar dari kerugian. Karena usaha tersebut memiliki nilai $\mathrm{CV}<0,5$ dan nilai $\mathrm{L}>0$, ini artinya usaha tambak udang pada setiap periodenya akan terhindar dari resiko produksi.

Analisis Resiko Pendapatan Usaha Budidaya Tambak Udang di Kelurahan Labuhan Deli Hasil penilaian resiko pendapatan pada usaha budidaya tambak udang dapat dilihat pada Tabel 7 berikut ini:

\begin{tabular}{|c|c|c|}
\hline No & Periode & Pendapatan (Rp/Ha) \\
\hline 1 & Musim 'l'ebar I & 6526368,57 \\
\hline 2 & Musim Tebar II & 6632055,71 \\
\hline 3 & Musim Tebar III & 6413122,96 \\
\hline & a Rata-rata(E) & 6523849,08 \\
\hline & b. Variance (V) & 11987647980,01 \\
\hline & c. Simpangan |3aku(V) & 109488,118 \\
\hline & d. Koevisien Variasi (KV) & 0,017 \\
\hline & e. Batas Bawah (L) & 6304872,84 \\
\hline
\end{tabular}

Sumber : Data Primer Diolah, 2015

Dari Tabel 7 dapat diukur besarnya pedapatan yang diharapkan dari kegiatan budidaya adalah Rp 6.483.059,61/Ha. Nilai ini menggambarkan pendapatan bersih yang diharapkan oleh petambak dimasa yang akan datang. Berdasarkan nilai simpangan baku diperoleh hasil sebesar 109.488,11. Simpangan baku merupakan besarnya fluktuasi pendapatan yang diperoleh, sehingga dapat dikatakan bahwa fluktuasi pendapatan atau resiko yang harus dihadapi usaha budidaya tambak udang berkisar Rp 109.488,118/Ha. Koefisien variasi diperoleh hasil sebesar 0,017. Artinya, untuk setiap Rp 1 return yang diterima petambak akan menghasilkan resiko sebesar Rp 0.017. Batas Bawah pendapatan (L) yang dihasilkan sebesar 6264083,37. Angka tersebut menunjukkan jumlah pendapatan terendah yang harus diterima oleh petambak udang dimasa yang akan datang adalah Rp 6.304.872,84/Ha.

Dilihat dari kriteria hubungan antara nilai CV dan L yaitu apabila CV > 0,5 maka $\mathrm{L}<0$, maka usaha tersebut akan berpeluang mengalami kerugian, apabila $\mathrm{CV}<0,5$ maka $\mathrm{L}>0$ maka usaha tersebut akan terhindar dari kerugian.Karena dari ketiga periode tersebut memiliki nilai $\mathrm{CV}<0,5$ dan 
nilai $\mathrm{L}>0$, ini artinya usaha tambak udang pada setiap periodenya akan terhindar dari kerugian atau resiko yang diderita akan kecil sekali.

Dari hasil perhitungan analisis resiko ketiga periode musim tebar tersebut, akan terhindar dari resiko atau memiliki resiko yang cukup rendah.

\section{SIMPULAN DAN SARAN}

\section{Simpulan}

1. Pendapatan petambak lebih besar dibandingkan dengan total biaya yang dikeluarkan selama proses budidaya. Hal ini berarti usaha budidaya tambak udang tersebut menguntungkan.

2. Resiko produksi petambak udang adalah sebesar 0,04. Namun secara keseluruhan dilihat dari tersebut memiliki nilai $\mathrm{CV}<0,5$ dan nilai $\mathrm{L}>0$, petambak udang tidak mengalami resiko terhadap produksi yang diperoleh

3. Usaha budidaya tambak udang yang dilakukan petambak memiliki nilai CV $<0,5$ dan nilai $\mathrm{L}>0$, berarti petambak terhindar dari resiko pendapatan. Hal ini dikarenakan kecinya resiko produksi yang dihadapi dan tingginya harga udang Windu tersebut.

\section{Saran}

1. Petambak udang diharapkan dapat mempertahankan usaha budidaya tambak udang windu mengingat secara ekonomi usaha ini menguntungkan dan resiko yang dihadapi kecil.

2. Pemerintah diharapkan dapat meningkatkan kegiatan penyuluhan bagi petani tambak udang agar petani dapat mengetahui cara penanggulangan serangan hama dan penyakit sehingga petani selalu terhindar atau memperkecil resiko pada usaha budidaya tambak udang Windu. 


\section{DAFTAR PUSTAKA}

Amri, K. 2003. Budidaya Udang Windu Secara Intensif. PT Agromedia Pustaka. Jakarta.

Arifin. 2013. Resiko Produksi dan Pendapatan Kepemilikan Lahan Daerah Sentra Produksi Padi di Kabupaten Pinrang. Jurnal Vegeta 7 (1) : 1-14.

Cahyono, B. 2008. Tomat; Usahatani dan Penanganan Pascapanen. Kanisius. Yogyakarta.

Heriani, dkk. 2013. Analisis Keuntungan dan Resiko Usahatani Tomat di Kecamatan Sumberejo Kabupaten Tanggamus. Jurnal IIA. 1 (2) : 169-173.

Ihsanudin. 2010. Resiko Usahatani Tembakau di Kabupaten Magelang. Jurnal Embryo. 7 (1) : 21-28.

Imelda. 2012. Analisis Resiko Pada Usaha Penangkapan Kepiting Bakau Di Kecamatan Sungai Kunyit Kabupaten Pontianak. Jurnal Sosial Ekonomi Pertanian. 1 (1) : 75-95.

Kadarsan, H.W. 1995. Keuangan Pertanian dan Pembiayaan Perusahaan Agribisnis. Cetakan Kedua. PT. Gramedia Pustaka Utama. Jakarta.

Mubyarto. 1989. Pengantar Ekonomi Pertanian. LP3ES. Jakarta.

Mulyadi. 2007. Akuntansi Biaya, edisi ke-5. Yogyakarta: Graha Ilmu.

Lamusa A. 2010. Resiko Usahatani Padi Sawah Rumah Tangga Di Daerah Impenso Provinsi Sulawesi Tengah. Jurnal Agroland. 17(3):226-232.

Scheaffer, L. Richard, William Mendenhall, Lyman Ott. 1990. Elementary Survey Sampling. PWS - Kent Publishing Company. Massachusetts. Boston.

Soekartawi. 1995. Analisis Usahatani. Universitas Indonesia (UI - Press). Jakarta. 